\title{
ЕФЕКТИ БЮДЖЕТУВАННЯ УПРАВЛІННЯ ЛЮДСЬКИМИ РЕСУРСАМИ В УМОВАХ ГЛОБАЛЬНИХ СОЦІОЕКОНОМІЧНИХ ЗМІН
}

\section{THE EFFECTS OF BUDGETING FOR HUMAN RESOURCE MANAGEMENT IN IN GLOBAL SOCIO-ECONOMIC CHANGES' CONDITIONS}

\author{
Кравчук Оксана Іванівна \\ кандидат економічних наук, доцент, \\ Київський національний економічний університет \\ імені Вадима Гетьмана \\ ORCID: https://orcid.org/0000-0002-6337-7759 \\ Варіс Ірина Олександрівна \\ кандидат економічних наук, доцент, \\ Київський національний економічний університет \\ імені Вадима Гетьмана \\ ORCID: https://orcid.org/0000-0002-9502-5045 \\ Дорош Марія Олегівна \\ здобувач вищої освіти, \\ Київський національний економічний університет \\ імені Вадима Гетьмана \\ ORCID: https://orcid.org/0000-0002-7350-9014
}

Kravchuk Oksana, Varis Iryna, Dorosh Mariia

Kyiv National Economic University named after Vadym Hetman

\begin{abstract}
У статті актуальним визначено пошук нових ефективних методів та інструментів бюджетування, які дозволять ідентифрікувати, оцінити та стимулювати потрібні для організації в умовах глобальних соціоекономічних змін ефекти бюджетування управління людськими ресурсами. Обґрунтовано значення та роль бюджетування управління людськими ресурсами в організації в умовах глобальних соціоекономічних змін. Визначено основні есректи для організації, які дає імплементація технології бюджетування в управління персоналом в організації. Зроблено висновки про необхідність стимулювання соціальних ефектів бюджетування управління людськими ресурсами в умовах глобальних соціоекономічних змін, поглиблений пандемією COVID-19. Розроблено методичні підходи до ідентифікації та оцінювання соціальних ефректів бюджетування управління людськими ресурсами.
\end{abstract}

Ключові слова: управління людськими ресурсами, управління персоналом, витрати на персонал, бюджетування, есректи бюджетування, hr бюджет.

В статье актуальным определен поиск новых эффективных методов и инструментов бюджетирования, позволяющих идентифицировать, оценить и стимулировать необходимые для организации в условиях глобальных социоэкономических изменений эфрфекты бюджетирования управления человеческими ресурсами. Обоснованы значение и роль бюджетирования управления человеческими ресурсами в организации в условиях глобальных социоэкономических изменений. Определены основные эффекты для организации, которые дает имплементация технологии бюджетирования в управление персоналом в организации. Сделаны выводы о необходимости стимулирования социальных эффеектов бюджетирования управления человеческими ресурсами в условиях глобальных социоэкономических изменений, усугубленных пандемией COVID-19. Разработаны методические подходы к идентификации и оценке социальных эфффектов бюджетирования управления человеческими ресурсами.

Ключевые слова: управление человеческими ресурсами, управление персоналом, расходы на персонал, бюджетирование, эфрфекты бюджетирования, hr бюджет. 
The need to budget the human resource management cost is relevant in the global socio-economic changes' context in recent years, deepened by the COVID-19 pandemic spread, which intensify the process of optimizing costs and investment in modern organizations. This activity is complicated by the fact that in today's rapidly changing conditions, all processes and procedures of human resource management need to be interconnected with the socio-economic goals of the organization, focus not only on economic but also on the social effects of investing in human resources. The article identifies the search for new effective methods and tools of budgeting, which will identify, assess, and stimulate the necessary for the organization in the global socio-economic changes' context, the effects of human resource management budgeting. The importance and role of human resources management budgeting in the organization in the global socio-economic changes' conditions are substantiated. The main organization effects, which gives the implementation of HR budgeting technology in the organization. Conclusions are made on the need to stimulate the social effects of budgeting for human resource management in the global socio-economic changes' context, deepened by the COVID-19 pandemic. Methodological approaches to the identification and evaluation of social effects of human resources management budgeting have been developed. The improving basis for the human resources management budgeting and the human resources management costs optimizing is the proposed standard process of human resources management budgeting, which can be implemented in the practice of management to achieve economic and social effects of organization. Its innovative economic effect will reduce turnover, increase productivity, strengthen human resources, and improve the quality of the services; its innovative social effects will be manifested in corporate social responsibility, employer brand improving, increasing competitiveness in the market, as well as in the loyalty and involvement of employees

Keywords: human resource management, personnel management, personnel costs, budgeting, budgeting effects, hr budget.

Постановка проблеми. Ефрективне планування та оптимальне проектування бюджетів витрат на персонал гарантує адекватне фрінансування для підтримки програм та ініціатив щодо управління людськими ресурсами. Необхідність бюджетування витрат на управління людськими ресурсами актуалізується в умовах глобальних соціоекономічних змін останніх років, поглиблених поширенням пандемії COVID-19, які активізують процеси оптимізації витрат та інвестицій в сучасних організаціях. Крім цього, забезпечення безперебійної реалізації кадрових програм в таких умовах потребує безперебійного їх фрінансування протягом року, передумовою якого $\epsilon$, насамперед, планування витрат на основні заходи політики управління людськими ресурсами організації. Ускладнюється така діяльність тим, що в сучасних швидкозмінюваних умовах потрібно усі процеси та процедури управління людськими ресурсами взаємопов'язувати 3 соціоекономічними цілями діяльності організації, орієнтуватися не тільки на економічні, а й на соціальні ефекти інвестування в людські ресурси.

Аналіз останніх досліджень та публікацій. Науковці В. Л. Дикань, Г. П. Заєць [4], Л. В. Синяєва [10], Я. В. Сердюк [8] розглядали витрати на людські ресурси через їх зв'язок з ефективністю підприємства та складову фрінансового планування. Багато вчених, а саме Д. В. Дячков, Є. І. Бурий, Ю. В. Вовковінський [5], Н. Л. Гавкалова та А. С. Криворучко [2], приділяли велику увагу у своїх працях оптимізації витрат на персонал та удосконаленні системи їх планування в орга- нізації. Дослідження Л. В. Фещенко [12] націлено на вдосконалення бюджетного плануванняю О. П. Гуцал [3], С. Я. Берсуцька [1] та С. А. Жуков [1; 6] висвітлювали бюджетування витрат на персонал з точки зору вдосконалення управління людськими ресрсами. Ю. П. Синиціна, С. М. Дунайчук та А. І. Алєксеенко [9] в своїх працях розглядали системні підходи да управління витратами на персонал. Серед закордонних вчених проблеми бюджетування управління людськими ресурсами розглянуті у працях С. Казмі, С. Хасну, Р. Яміл [15] та В. Ф. Кашіо, А. А. Фінк і Дж. Будро [14]. Проте в науковій думці відсутнє єдине чітке визначення ролі та оцінювання ефектів бюджетування витрат на реалізацію фрункції управління людськими ресурсами в організації.

Постановка завдання. Тому актуальним $€$ пошук нових ефективних методів та інструментів бюджетування, які дозволять ідентифікувати, оцінити та стимулювати потрібні для організації в умовах глобальних соціоекономічних змін економічні та соціальні ефекти бюджетування управління людськими ресурсами.

Виклад основного матеріалу дослідження. Бюджетування управління людськими ресурсами $€$ важливою складовою загальної фрінансової стратегії організації. Бюджет витрат на людські ресурси (далі - HR бюджет) надає огляд завдань системи управління людським ресурсами та обсягів їх необхідного фрінансування для досягнення організаційних цілей. HR бюджет передбачає річний прогноз витрат, пов'язаних 3 людськими ресурсами в організації, та надає організації прогнозовані роз- 
рахункові показники, які будуть використані при складанні річного бюджету. Бюджетування управління людськими ресурсами передбачає систематичний збір інформації та даних, щоб можна було проектувати фрінанси, необхідні для підтримки організаційних кадрових цілей. Більшість організацій мають регламентований процес розроблення бюджету управління людськими ресурсами. До процесу бюджетування управління людськими ресурсами організація має завершити стратегічне планування для визначення річних цілей і завдань. Це дозволить департаменту з управління людськими ресурсами сконцентрувати виділені бюджети на підтримці цих цілей. Бюджетування вимагає збору великих масивів даних, які 3 точки зору людських ресурсів, необхідні для створення нового HR бюджету, зокрема щодо прогнозованої на наступний рік чисельності персоналу, ефектів збільшення витрат на персонал, прогнозованого зростання заробітної плати, фрактичних витрат на управління людським ресурсами у поточному році, заплановані нові HR програми та інші зміни в політиці, бізнес-стратегії та законодавчому регулюванні, які можуть вплинути на витрати на людські ресурси організації.

У сучасні науковій думці та прикладних дослідження існує спотворене розуміння терміну «бюджет людських ресурсів», яке зводить весь процес бюджетування тільки до планування витрат, пов'язаних з добором персоналу та формуванням фонду заробітної плати. Насправді, перспектива застосування бюджетування управління людськими ресурсами набагато ширша, оскільки дозволяє організації мати чітке уявлення про якісну і кількісну потребу в людських ресурсах для досягнення стратегічних цілей розвитку організації. Тому важливість бюджетування управління людськими ресурсами не можна недооцінювати, оскільки воно є основою забезпечення необхідного фрінансування бізнес-процесів управління людськими ресурсами організації, дозволяє набирати і утримувати кращий різноманітний пул талантів. Тому, на нашу думку, основі ефректи, які бюджетування процесів управління людськими ресурсами може принести для організації та системи менеджменту персоналу, включають:

1. Запобігання надмірному найманню працівників, яке виникає в умовах, коли організація приділяє занадто багато зусиль для наймання нових працівників, а не інвестує в навчання та розвиток власного персоналу. В умовах нової реальності багато сучасних компаній виявили проблеми та помилки в доборі персоналу, які характеризувались найманням більшої чисельності працівників, ніж роботодавці можуть належним чином контролювати та навчати, не кажучи вже про його утримання. Особливо ці аспекти загострилися під час запровадження роботи 3 дому та дистанційної зайнятості, пов'язаних 3 потребою соціального дистанціювання під час запровадження локдаунів через загострення пандемії COVID-19. Роботодавці не можуть зараз дозволити собі наймати більше працівників, ніж потрібно, а бюджетування управління людськими ресурсами може допомогти стримати надмірні витрати на наймання надлишкових працівників.

2. Допомога організаціям у систематизації та уніфрікації вимог до персоналу, оскільки Бюджетування управління людськими ресурсами допомагає управлінню якісними характеристиками персоналу, забезпечуючи еорективну профресійно-кваліфрікаційну структуру, розроблену для задоволення унікальних потреб організації та її ключових стейкхолдерів. Реалістичне бюджетування допомагає керівникам системи управління людськими ресурсами приймати розумні кадрові рішення, таким чином, організація може стратегічно планувати фрінансові витрати на людські ресурси. Це допомагає аналізувати основні показники системи управління людськими ресурсами, як наприклад, витрати на одного працівника в цілому та для різних HR-цілей, покращувати навички стратегічного планування. Бюджетування управління людськими ресурсами також дозволяє організації ефективно розподіляти обмежені ресурси, ресурси на заробітну плату між конкретними групами або особами, таким чином, допомагає досягти бажаного рівня персоналу та запобігти високій плинності, уникнути погіршення соціальнопсихологічного клімату.

3. Запобігання нестачі людських ресурсів через збільшення плинності персоналу, що збільшує витрати на добір персоналу; через зниження продуктивності працівників, що збільшує витрати роботодавців; через погіршення морального духу працівників, що знижує мотивацію та продуктивність команди. Скорочення цих витрат та втрат організації може бути досягнуто через запровадження чіткого і послідовного бюджету компенсацій, який координує всі види діяльності. Ефективне складання такого бюджету гарантує досягнення оптимальної чисельності персоналу організації та раціонального розподілу ресурсів. Ефективний розподіл ресурсів усу- 
ває проблему нестачі людських ресурсів, що дозволяє працівникам досягати максимальних очікувань продуктивності без шкоди для фрінансових результатів організації.

4. Сприяння залученню талановитих працівників, тому що однією 3 можливостей покращення здатності організації залучати й утримувати працівників $\epsilon$ розроблення комплексної системи бюджетування людських ресурсів. Така система може бути використана для розподілу ресурсів на найкритичніші витрати, пов'язані з добором нових працівників, включаючи заробітну плату та пільги.

5. Зменшення плинності персоналу, тому стратегія бюджетування людських ресурсів має вирішальне значення для організації, особливо з високою плинністю кадрів. Це вимагає значних аналітичних здібностей і вміння приймати управлінські рішення, аналізуючи показники плинності персоналу.

Добре спланований і продуманий бюджет гарантує, що HR отримує необхідне фрінансування для підтримки програм та ініціатив працівників, критично важливих для залучення та утримання кваліфрікованої робочої сили. За таких умов очевидною $€$ необхідність у трансорормації підходів до фрормування есрективного HR бюджету організації, які, на нашу думку, мають визначати та розглядати важливі ресурси, необхідні протягом кожного етапу року; зосереджуватися на необхідних елементах без перевитрат на пільги для працівників, які не потрібні організації; бути націленими на створення такого бюджету, який сприятиме зростанню організації. Реалізація такого підходу до планування витрат в управлінні людськими ресурсами можлива через впровадження в практику управління витратами технологій бюджетування, які являють собою сукупність управлінських процесів забезпе- чення життєвого цикл бюджету, зокрема, найбільш поширених і найчастіше використовуваних підходів до складання бюджету витрат, а саме традиційного бюджетування, бюджетування з нульовою базою та надбудовне бюджетування. Традиційне бюджетування також має назву бюджет, що складений за аналогією, а його сутність полягає, в тому що при складані нового бюджету на наступний період до уваги беруться дані за минулий період, найчастіше це бюджет попереднього року. У свою чергу, бюджет 3 нульовою базою суттєві відрізнявся від традиційного бюджетування, тому що планування починається на нульові основі і кожна стаття витрат повинна бути належно обґрунтована. Надбудовне бюджетування полягає у розподілі отриманої виручки організації на різні групи витрат та прибуток залежно від фріксованої процентної частки.

SHRM визначає два поширеними методами бюджетування управління людськими ресурсами: додаткове бюджетування з використанням поточного бюджету, за якого новий бюджет розробляється шляхом внесення коригувань вгору або вниз до кожної статті на основі очікувань та нульове бюджетування кожен пункт, включений до бюджету, повинен бути виправданий перед включенням; тому процес починається 3 чистого аркуша [16]. Задля вибору найкращого методичного підходу до бюджетування управління людськими ресурсами потрібно проаналізувати перераховані підходи, їх сильні і слабкі сторони 3 точки зору переваг та недоліків (табл. 1).

На основі інтерпретованої інформації в табл. 1, ми можемо зробити висновки, що найкращим методом бюджетування, що можна застосувати до витрат на управління людськими ресурсами $€$ бюджетування 3 нульовою базою. Даний підхід заснований

Таблиця 1

Порівняльний аналіз підходів до бюджетування управління людськими ресурсами

\begin{tabular}{|c|c|c|c|}
\hline & $\begin{array}{l}\text { Традиційне } \\
\text { бджетування }\end{array}$ & $\begin{array}{l}\text { Бюджетування } 3 \\
\text { нульовою базою }\end{array}$ & $\begin{array}{c}\text { Надбудовне } \\
\text { бюджетування }\end{array}$ \\
\hline Переваги & $\begin{array}{l}\text { - обґрунтованість розра- } \\
\text { хунків; } \\
\text { - низькі витрати часу; } \\
\text { - простота та інтуїтивна } \\
\text { зрозумілість } \\
\end{array}$ & $\begin{array}{l}\text { - всі дані підкріплюються } \\
\text { розрахунками; } \\
\text { - не залежить від етапу } \\
\text { формування організації } \\
\text { та умов поза і в середині }\end{array}$ & $\begin{array}{l}\text { - процентне вираження } \\
\text { витрат; } \\
\text { - не потрібний традицій- } \\
\text { ний бюджетний цикл }\end{array}$ \\
\hline Недоліки & $\begin{array}{l}\text { - не підходить для ново- } \\
\text { створених організацій; } \\
\text { - спотворення за рахунок } \\
\text { не вірних підсумків мину- } \\
\text { лого періоду }\end{array}$ & $\begin{array}{l}\text { - тривалість та трудоміст- } \\
\text { кість розрахунків }\end{array}$ & - низька об'єктивність \\
\hline
\end{tabular}

Джерело: розроблено авторами на основі [1; 13] 
на аналітиці, а не на збільшені витрат поточного періоду до минулого, тобто він дозволяє викорінити з системи неефективність розподілу фрінансових ресурсів. Проте ефективним способом для застосування в сорері планування витрат на людські ресурси є поєднання традиційного бюджету та нульової основи, оскільки останній $€$ достатньо трудомістким та затратним, то його застосування можна обмежити невеликою періодичністю, а в інші періоди застосовувати традиційний.

Для підвищення ефрективності розроблення та складання фрункціональних бюджетів витрат на людські ресурси, на нашу думку, необхідно використовувати такі методи планування, як: прямий, за якого визначається сума всіх витрат, які організація планує витратити, на напрямки роботи 3 персоналом; укрупнений, за якого бюджет розраховується на основі витрат попереднього періоду, індексів інсрляції та середньої заробітної плати, а також планової кількості вакансій та їх вартості; по аналогії, за якого здійснюється встановлення частки витрат у відсотках від виручки чи прибутку; ринковий, при використанні здійснюється орієнтація на середній рівень витрат конкурентів; нормативний, за якого застосування певних нормативів при плануванні об'єму витрат [12]. Відповідно для вибору найкращого методу бюджетування управління людськими ресурсами, потрібно проаналізувати їх з точки зору переваг та недоліків (табл. 2).

На нашу думку, найефективнішим для застосування у практиці бюджетування управління людськими ресурсами є прямий метод, тому що він передбачає глибоку аналітику 3 обґрунтованими висновками, а також врахування планів діяльності служби персоналу та загальних планів і цілей діяльності організації. Хоча він і $€$ складним в розрахунках та трудомістким, але це винагороджується ефрективністю розподілу фрінансування. Беззаперечно процес бюджетування управління людськими ресурсами потребує вдосконалення відповідно до сучасних трендів розвитку $з$ метою адаптації до змін внутрішнього та зовнішнього середовища, оскільки в таких умовах змінюється вимоги до працівника, його потреби і мотиви. 3 цією метою для удосконалення та оптимізації бюджетування управління людськими ресурсами ефрективно можуть бути використані сучасні інноваційні методико-інструментальні способи, а саме: HR-метрики для дослідження тенденцій зміни показників для аналітики і визначення критичних точок, тобто аналізу різних статей витрат та визначення їх ефрективності; зовнішній та внутрішній бенчмаркінг для впровадження досвіду еталонних компаній; SWOT-аналіз для пошуку нових можливостей, резервів та передбачення ризиків і загроз; оптимізація бізнес-процесів для застосування реінжинірингу процесу бюджетування, його аналізу та вдосконалення; експертні опитування для збору інфрормації та пропозицій від працівників 3 метою розуміння ситуації з токи зору суб'єктів, на які прямо впливають HR-витрати; перегляд статей витрат бюджету, зокрема, витрат на соціальний пакет, корпоративні заходи, організацію праці тощо; зміна бюджету, його деталізація чи укрупнення з метою перерозподілу фрінансових ресурсів та фрормування резервних фоондів.

Процес оптимізації бюджету управління людськими ресурсами має типову послідовність процедур та операцій, які здійснюються 3 метою його організації та забезпечення висо-

Таблиця 2

Порівняння методичних підходів бюджетування управління людськими ресурсами

\begin{tabular}{|c|c|c|}
\hline Методичні підходи & Переваги & Недоліки \\
\hline Прямий & $\begin{array}{c}\text { прозорий та простий } \\
\text { у застосуванні }\end{array}$ & трудомісткий \\
\hline Укрупнений & $\begin{array}{c}\text { не вимагає великих затрат } \\
\text { на розрахунки }\end{array}$ & неточність даних розрахунків \\
\hline По аналогії & простий у використанні & $\begin{array}{c}\text { вимагає детального аналізу } \\
\text { та планування, проблема з подальшиим } \\
\text { розподілом коштів між працівниками }\end{array}$ \\
\hline Ринковий & $\begin{array}{c}\text { простий, зручний } \\
\text { та наявність достатньої } \\
\text { кількість інформації }\end{array}$ & $\begin{array}{c}\text { проблема подальшого розподілу коштів } \\
\text { між працівниками }\end{array}$ \\
\hline Нормативний & можливість розробити власні & $\begin{array}{c}\text { відсутність законодавчо закріплених } \\
\text { нормативів }\end{array}$ \\
\hline
\end{tabular}


кої ефрективності. Перший етап, підготовчий, розпочинається, коли усвідомлена необхідність оптимізації витрат на людські ресурси; він складається $з$ оцінки поточних HR-витрат та виявлення їх впливу на ефективність діяльності організації. Наступний етап $€$ основним і полягає в визначені резервів на оптимізацію бюджету. Заключний етап включає перерозподіл коштів на персонал і проведення розрахунків щодо відповідності оптимізації; його кінцевим результатом мають стати оптимізовані витрати на людські ресурси організації [2]. На нашу думку, така послідовність процесу оптимізації бюджету управління людськими ресурсами може стати підґрунтям для розроблення проєктів з оптимізації витрат на персонал за умови ії доповнення додатковими процедурами та операціями. Так, під час розроблення потрібно виділити точки контролю та точки росту для розуміння того, на скільки оптимізація $€$ вдалою та ефективною. Крім цього, обов'язково мають бути включені у цю процедуру заходи щодо дослідження та включення в оптимізацію бюджету думки і пропозицій працівників організації, тому оптимізація напряму вплине на їх трудову діяльність.

Будь-які витрати в організації направлені на отримання позитивних результатів. Це стосується і витрат на людські ресурси, тому потрібно здійснювати моніторинг їх ефрективності. У цьому контексті варто зауважити, що у науковій літературі одностайно приходять до думки про єдність соціальної і економічної ефективності роботи 3 персоналом. Наслідком цього $€$ виникнення основних напрямів оцінювання есрективності витрат на персонал: інтегральної ефективності в цілому, та економічної, соціальної, організаційної та технологічної ефрективності, зокрема [11]. Проте, на нашу думку, інфрормативнішим і доцільнішим в застосуванні $€$ оцінювання ефективності 3 точки зору економічних і соціальних ефектів. Тому для аналізу економічної ефективності використання людських ресурсів і відповідно витрат на них можуть бути використані показники: частки витрат на персонал в обсязі реалізації, які характеризують частину валової виручки організації, яка витрачається на людські ресурси, та розраховуються як відношення загальної величини витрат на персонал на обсяг реалізації за період; витрат на одного працівника, як співвідношення загальної величини витрат на працівників за період до середньооблікової чисельності персоналу; витрат на одну продуктивну годину, які показують скільки в середньому організа- ція витрачає на 1 годину продуктивної праці 3 точки зору витрат на людські ресурси, та розраховуються як співвідношення загальних витрат на персонал до загальної трудомісткості продуктивної роботи [7]. Така розширена HR аналітика, на нашу думку, може стати об'єктивною основою для відслідковування тенденцій витрат на людські ресурси. Проте до системи цих HR-метрик потрібно, на нашу думку, додати розрахунок затратомісткості, як співвідношення витрат на управління людськими ресурсами до доходу організації; а також обернений показник витратовіддачі, як співвідношення доходу до витрат. Проте вони не завжди можуть дати повну картину, тому що існують додаткові змінні, що впливають на результат, тому потрібно обов'язково оцінювати соціальний ефект від витрат на людські ресурси організації.

На нашу думку, ілюструвати соціальні есректи від витрат на людські ресурси організації можуть: зменшення плинності персоналу i, як наслідок, зменшення подальших витрат на добір та адаптацію нових працівників, зниження простою робочих місць та посад, збільшення продуктивності праці та прибутку; покращення бренду роботодавця, в тому числі збільшення привабливості роботи в організації та підвищення конкурентоспроможності робочого місця; збільшення лояльності та задоволеності працівників, зокрема, шляхом підтримки цінностей та місії організації, а також зменшення опору змінам і ресрормам, тобто через управління корпоративною культурою та управління змінами; покращення фрормування кадрового резерву, як наслідок, розвиток працівника як професіонала, планування та організація його кар'єрного зростання; фрормування стабільності та захищеності в працівників.

Отже, можемо зробити висновок, що задля есрективного планування витрат на управління людськими ресурсами при складанні бюджету потрібно орієнтуватись на вдале поєднання методичних підходів до планування бюджету та методів його безпосереднього складання, враховувати їх переваги та недоліки. 3 метою проведення оптимізації витрат на управління людськими ресурсами доцільно реалізовувати заходи, що базуються на застосуванні практичних підходів та підкріплені великими масивами аналітичних даних. Їх аналіз та оцінювання ефрективності має проводитись 3 точки зору економічного та соціального аспектів.

Для досягнення економічних та соціальних ефректів бюджетування управління людськими 
ресурсами рекомендовано впроваджувати типовий процес бюджетування управління людськими ресурсами, який базується на послідовній реалізації дев'яти обов'язкових процедур. На рис. 1 наведена схематична модель даного бізнес-процесу.

Перший етап процесу полягає в ґрунтовному аналізі показників і об'ємів витрат на управління людськими ресурсами за попередній рік, що дасть розуміння структури статей витрат та їх вагомості; розміру та динаміки загальних фрактично виділених фрінансових ресурсів; розподілу витрат за спрямуванням і їх співвідношення. На етапі визначення цілей організації на поточний рік, а також окреслення планів і стратегії служби персоналу відносно роботи з персоналом, потрібно обов'язково враховувати ці дві змінні і забезпечувати їх нерозривний зв'язок, а також слідкувати за відсутністю їх суперечностей. Це цілком логічно, тому що для організації людський ресурс $€$ одним 3 основних для досягнення організаційних цілей, а суб'єкти управління людськими ресурсами мають докладати зусиль для підтримки їх продуктивної роботи і результативності. Етап оцінки фрінансового стану організації $€$ не менш важливим, тому що витрати на людські ресурси виділяє зі свого прибутку або резервних фондів. Тому, коли організація збиткова чи показує не стабільні результати, збільшення обсягів витрат на персонал стає неможливим. При зборі інфрормації від працівників потрібно враховувати, що бюджетування має спиратись на принцип відкритості і тому обов'язково в підготовці та проведені даного процесу бюджетування управління людськими ресурсами потрібно залучати працівників організації. Найкращим способом є проведення опитування серед працівників щодо їх погляду на витрати, які безпосередньо стосуються їх трудової діяльності. Даний спосіб простий у розробці, проведенні та інтерпретації результатів, тому що не потребує великих фрінансових та часових затрат, простий у розумінні та не вимагає спеціальної кваліфрікації відповідальної особи. При зведенні та опрацюванні отриманої в результаті проведення попередніх етапів аналітичної інформації важливо виділити ключові елементи, які буть використовуватись далі, зокрема, частку витрат, який може виділити організація на людські ресурси; пріоритетні напрямки роботи з працівниками; потребу в персоналі організації тощо. При визначення статей витрат на людські ресурси на основі попереднього аналізу відповідальна за даний процес особа повинна зазначити, які витрати на персонал будуть закладені в бюджет наступного року. Етап розробки та планування тісно пов'язаний з попереднім етапом і націлений на обґрунтування розподілу витрат на управління людськими ресурсами за статтями; виокремлення та закріплення бюджетів цих витрат; розроблення документаційних фрорм цих бюджетів; офрормлення прикінцевого варіанту бюджетів для їх подальшої передачі на затвердження. Захист HR бюджету має бути проведений після того як розроблено кінцевий його варіант і полягає у представлені

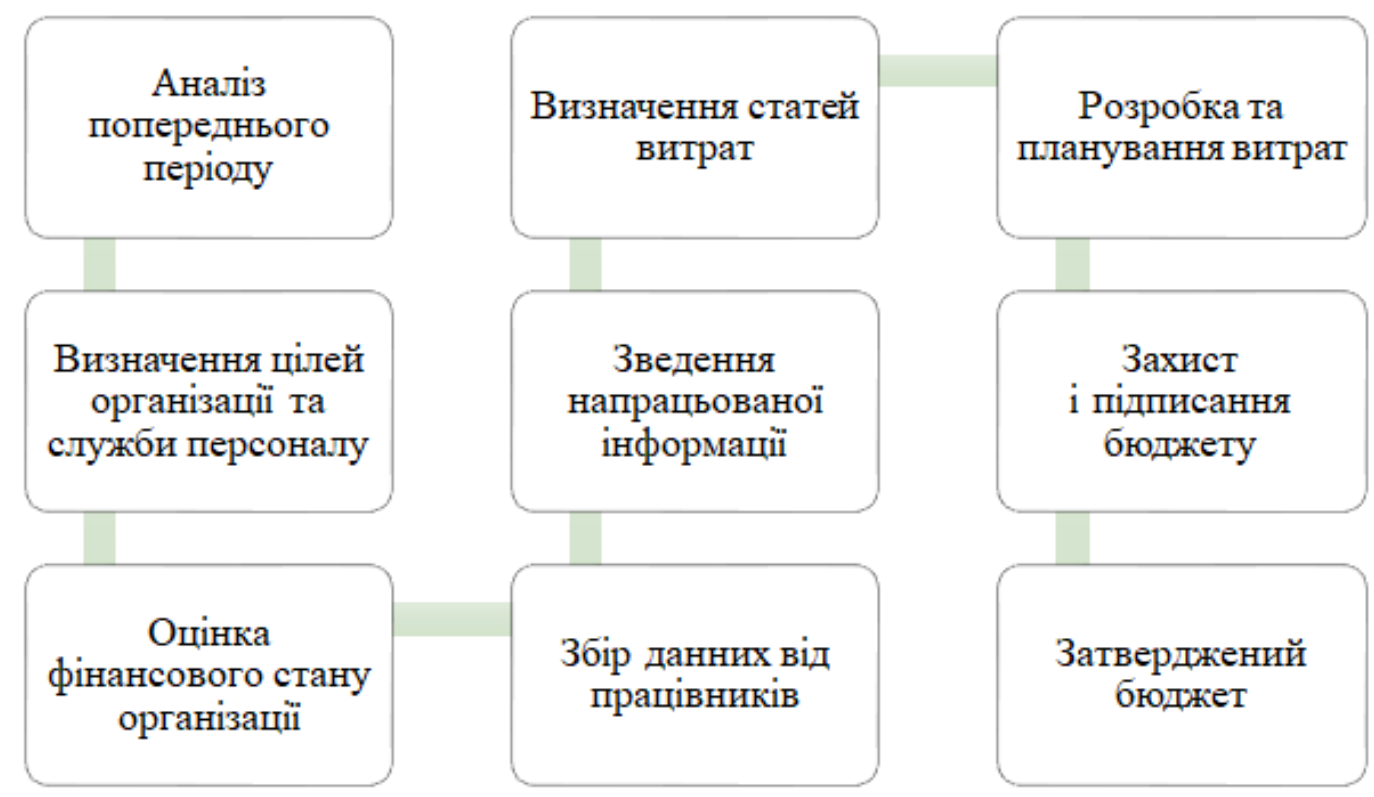

Рис. 1. Процес бюджетування витрат на персонал Джерело: розроблено авторами на основі [8] 
керівництву основних статей витрат, захисті та підписанні. Тому відповідальна особа повинна сорормувати бюджет на наступний період, привести вагомі аргументи на його користь, довести його раціональність та ефективність, а також в кінцевому результаті отримати схвалення бюджету за статтями витрат. На даному етапі можливе внесення коригувань відповідно до побажань та пропозицій керівництва, а після такого доопрацювання затверджується офріційно кінцевий варіант HR-бюджету, які починаючи 3 наступного року вступають в дію та виконуються.

Для логічного і обґрунтованого визначення витрат на управління людськими ресурсами i проведення процесу їх бюджетування потрібно враховувати потреби, побажання та пропозиції персоналу організації. Працівники є основним об'єктом, на який впливає дана група витрат, а тому важливо враховувати їх думку. Метою такого опитування $€$ залучення персоналу в про- цес бюджетування витрат на управління людськими ресурсами та їх можливість вплинути на їх структуру та розмір. Опитування потрібно проводити на відповідному етапі процесу бюджетування витрат для зміни та оптимізації статей витрат відповідно до запитів персоналу.

Ефрективність будь-якого удосконалення, впровадження, змін може розглядатись 3 двох точок зору: економічного та соціального ефектів. Усі заходи вдосконалення та оптимізації бюджетів витрат на управління людськими ресурсами мають принести позитивні наслідки, а також мати ряд переваг, що актуалізує та підтверджує важливість для їх впровадження. Переваги від впровадження процесу бюджетування управління людськими ресурсами зображено на рис. 2.

Даний захід допоможе оптимізувати витрати на управління людськими ресурсами за допомогою систематичності та чіткого планування. На рис. 3 перелічено переваги постійного про-

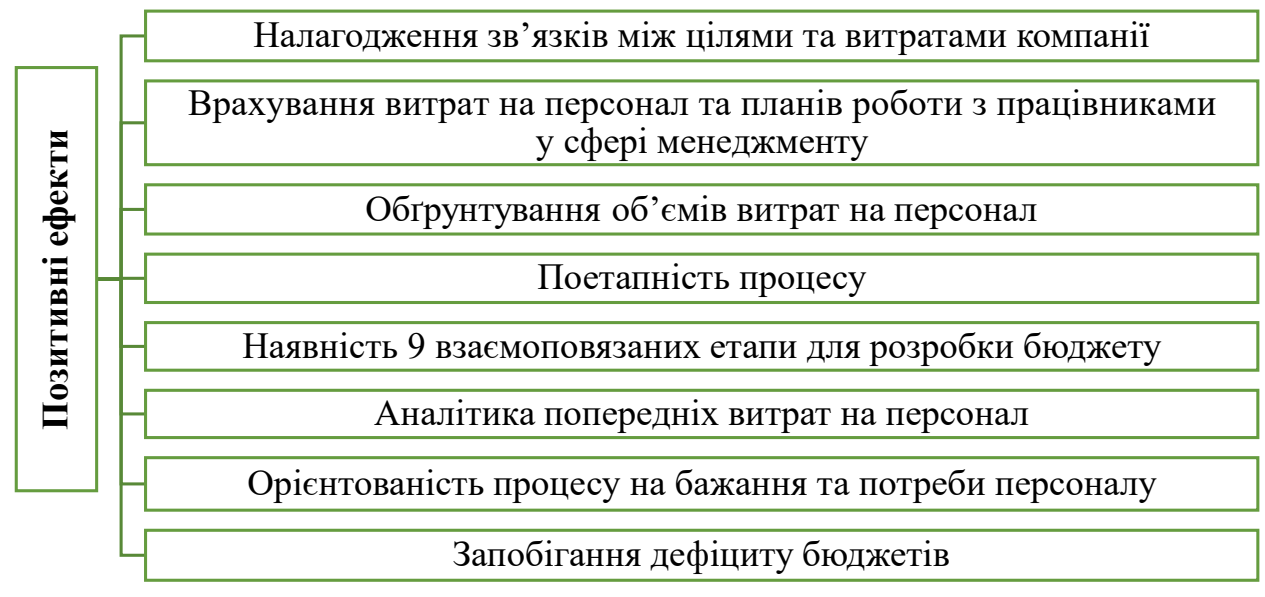

Рис. 2. Позитивні ефекти від впровадження процесу бюджетування управління людськими ресурсами

Джерело: розроблено авторами

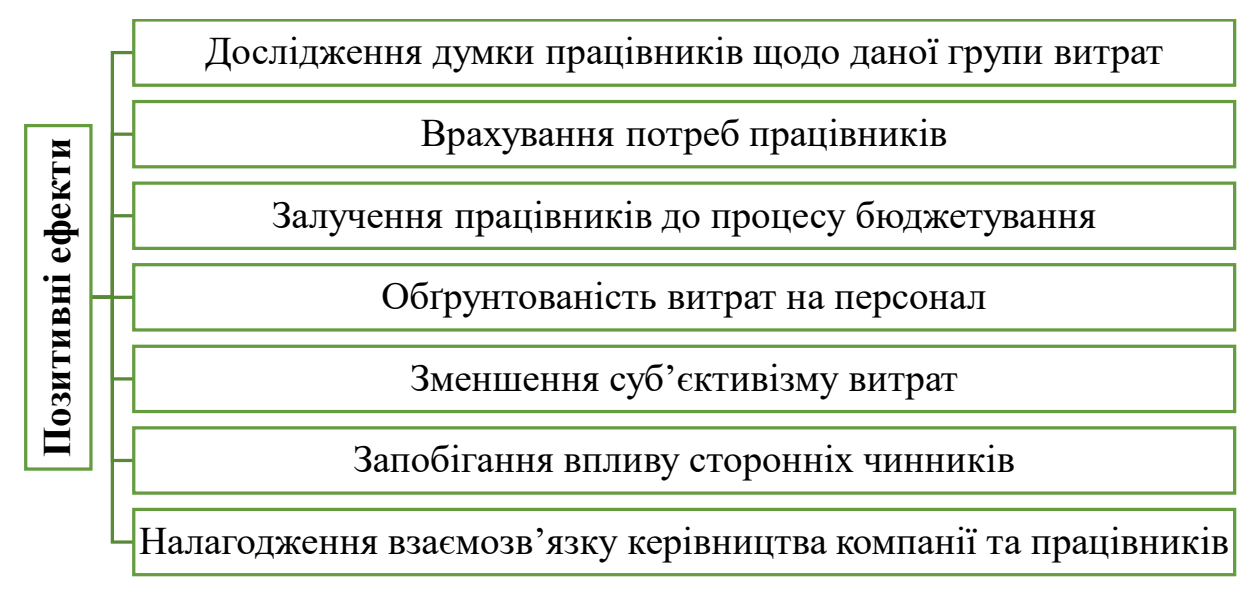

Рис. 3. Позитивні ефекти від проведення опитування працівників 
ведення опитування серед працівників щодо витрат, які стосуються їх на пряму.

При постійному проведенні опитувань працівників, статті витрат на управління людськими ресурсами не будуть іти в розбіжності 3 потребами працівників, та одночасно матимуть ефрективність та значимість для організації в цілому.

Розробка фрункціональних бюджетів витрат на управління людськми ресурсами та впровадження їх в організації має позитивні сторони такі, як чіткий розподіл фрінансування за бюджетами, наочність, структурність та дисреренціація витрат на персонал. Впровадження фрункціональних бюджетів допоможе організації максимально раціонально розподілити обсяги фрінансування, запобігти дефріциту бюджету на ранніх строках, а також в подальшому спростити аналітику даних та планування на майбутні періоди.

Безпосередньо узагальнення економічних і соціальних ефектів запропонованих заходів з точки зору доцільності їх впровадження в організації, представлено на рис. 4.

Якщо працівники усвідомлюють свою значимість для організації, зв'язок 3 керівництвом, а також можливість впливати на управлінські рішення, то вони не будуть шукати можливості змінити поточне місце роботи. Зі зменшенням плинності персоналу організація зможе мінімізувати витрати на добір, адаптацію та навчання новоприйнятих працівників i, тим самим, не буде втрачати можливий прибуток. 3 цього також випливає подальше підвищення продуктивності праці персоналу.
Також працівники за рахунок тривалої трудової діяльності в організації в подальшому можуть ставати керівниками і при розширенні компанії будуть брати на себе відповідальність, тобто ставати надійними партнерами для бізнесу. Відповідно чим більше працівники працюють в сорері тим більше вони $\epsilon$ профресіоналами своєї справи, а тому якість послуг компанії буде безперервно покращуватись. Так як компанія буде намагатись покращити умови праці персоналу, то відповідно це буде говорити про соціально орієнтовану її відповідальність перед своїми працівниками, що $є$ важливим в сучасних умовах, викликаних пандемією COVID-19. Також буде помітно збільшення лояльності та залученості працівників, оскільки вони будуть відчувати приналежність до організації і, тим самим, зменшувати незадоволеність праці. Бренд роботодавця та конкурентоспроможність тісно між собою пов'язані. Компанія, яка дбає про свій персонал є більш привабливішою для працевлаштування, що скоротить затрати на пошук працівників. До того ж без вмотивованих працівників і інвестицій в них на даний час не можливо забезпечувати свою стабільність на ринку.

Кінцева мета бюджетування управління людськими ресурсами підвищити прибутковість та вартість компанії. Ніякі заходи служби персоналу окремо не мають значення без впливу на збільшення прибутку компанії та її вартості на ринку. Тому важливо, щоб комплексне оцінювання есрективності бюджетування управління людськими ресурсами, як

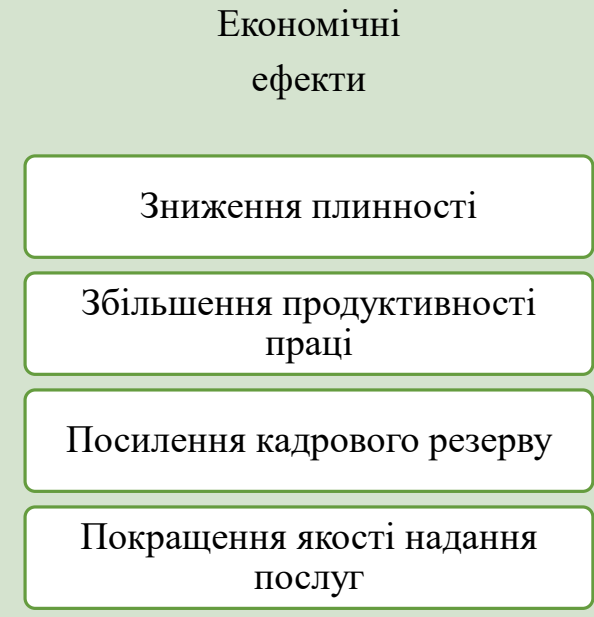

Рис. 4. Економічні та соціальні ефекти від впровадження бюджетування управління людськими ресурсами
Соціальні

ефекти

Підвищення соціальної відповідальності компанії

Збільшення лояльності, залученості працівників

Покращення бренду роботодавця

Конкурентоспроможність компанії на ринку 
і самих статей витрат бюджет, проводилась системно та з точки зору їх впливу на фрінансові показники компанії за двома напрямками: максимізація людського капіталу, чи підвищення ефективності персоналу, та оптимізація (мінімізація) видатків на персонал. Тому загально-організаційні ефекти від впровадження бюджетування управління людськими ресурсами полягають в уникненні перевитрат або нестачі фрінансування основних напрямів політики управління людськими ресурсами, можливості перерозподілу ресурсів у випадку змін; а також вдосконаленні управління витратами людського капіталу. Крім цього, воно націлене на забезпечення операційної есрективності управління людськими ресурсами, формування розуміння каналів витрат, що дає змогу діяти еорективно; досягнення організаційного успіху - завдяки ефективності роботи з персоналом організації можуть отримати максимум від свого персоналу, бути продуктивними та досягати своїх цілей.

Висновок. Дієвим інструментом в системі управління людськими ресурсами при впровадження технології планування витрат на персонал організації $є$ бюджетування, есрективність якого досягається за рахунок оперативності обробки та інтерпретації інфрормації, тому він грає вирішальну роль в безпосередньому оцінюванні ефективності витрат на управління людськими ресурсами та їх розподілу між суб'єктами. В загальному бюджетування управління людськими ресурсами визначено як синергетичну управлінську технологію, що передбачає планування, організацію, реалізацію та оцінку ефективності витрат на працівників організації в певний період, яка спрямована на ефрективний розподіл коштів задля забезпечення їх продуктивної трудової діяльності у розрізі результатів компанії і містить деталізовану інсрормацію для подальшої аналітики з точки зору менеджменту.

Оптимальними підходами до бюджетування управління людськими ресурсами визначено традиційне бюджетування, бюдже- тування 3 нульовою базою та надбудовне бюджетування, серед яких в умовах глобальних соціоекономічних змін найбільш ефективним $€$ бюджетування 3 нульовою базою, тому що цей підхід заснований на аналітиці, тобто він певною мірою дозволяє викорінити з системи неефективність розподілу коштів. Серед основних методів бюджетування рекомендовано при цьому використовувати прямий метод, який $є$ достатньо ефективним для розподілу фрінансування. Серед основних методів оптимізації бюджетів управління людськими ресурсами виділено: HR-метрики, бенчмаркінг, SWOT-аналіз, оптимізація бізнес-процесів, експертні опитування, перегляд статей бюджету та його зміна $є$ ефективними методами в процесу оптимізації даних бюджетів.

Критерії оцінювання есрективності підходів і методів бюджетування управління людськими ресурсами були розглянуті з точки зору економічних і соціальних ефректів для організації. 3 метою їх оцінки визначено оптимальним до використання в організації періодичне опитування працівників щодо їх потреб та доцільності витрат на персоналу, що може стати основою раціонального розподілу витрати, а також створить для працівників максимально комсрортні умови праці. Основою вдосконалення бюджетування управління людськими ресурсами та оптимізації витрат управління людськими ресурсами визначено запропонований стандартизований типовий процес бюджетування управління людськими ресурсами, який може бути імплементований в практику менеджменту персоналу компанії з метою досягнення економічного та соціального ефректів. Економічний ефект від даних нововведень полягатиму у зниженні плинності, збільшенні продуктивності праці, посиленні кадрового резерву та покращення якості надання послуг. щодо соціальних ефектів, то вони проявляться в соціальній відповідальності компанії, покращенні бренду роботодавця, збільшення конкурентоспроможності на ринку, лояльності та залученості працівників.

\section{СПИСОК ВИКОРИСТАНИХ ДЖЕРЕЛ:}

1. Берсуцька С. Я., Жуков С. А. Соціальна роль системи бюджетування на промислових підприємствах України. Научный вестник Донбасской государственной машиностроительной академии. 2017. № 1. С. 112-119.

2. Гавкалова Н. Л., Криворучко А. С. Процедура оптимізації витрат на персонал. Теорія та практика державного управління. 2011. 4. 156-161.

3. Гуцал О. П. Бюджет витрат на персонал у системі бюджетів підприємства. Соціально-трудові відносини: теорія та практика. 2014. № 1. С. 402-407.

4. Дикань, В. Л., Заєць Г. П. Забезпечення ефективності менеджменту промислових підприємств на засадах управління витратами на персонал. Вісник економіки транспорту і промисловості. 2018. № 62. С. 297-305. 
5. Дячков Д. В., Бурий Є. І., Вовковінський Ю. В. Оптимізаційне управління витратами на персонал в умовах економічної нестабільності. Економічний форум. 2018. № 1. С. 165-171.

6. Жуков С. А. Роль бюджетування в системі стратегічного управління людським капіталом промислового підприємства. Економічний вісник Донбасу. 2017. № 2(48). С. 214-219.

7. Збрицька Т. П., Сало Я. В. Аудит персоналу : навчальний посібник. Одеса : ОНЕУ, 2019. 381 с.

8. Сердюк Я. В. Бюджетування як складова фрінансового планування на підприємстві. Міжнародний науковий журнал «Інтернаука». 2016. № 12(22). С. 141-145.

9. Синиціна Ю. П., Дунайчук С. М., Алєксеенко А. І. Управління витратами на персонал на основі системного підходу. Економіка і суспільство. 2017. № 9. С. 636-641.

10. Синяєва Л. В. Взаємозв'язок планування витрат на персонал з критеріями ефективності. Бізнес-інкубamop. 2017. URL: http://elar.tsatu.edu.ua/bitstream/123456789/4694/1/5-1-74-77.pdf

11. Управління персоналом : підручник / В. М. Данюк та ін. Київ : КНЕУ; Краматорськ : НКМЗ, 2013. 666 с.

12. Фещенко Л. В. Вдосконалення бюджетного планування і прогнозування. Вісник економіки транспорту і промисловості. 2011. № 34. С. 154-157.

13. Ювженко Н. М. Традиційні та сучасні методи бюджетування: переваги і недоліки. Бізнес Інфрорм. 2018. № 7. C. 239-245.

14. Cascio, W. F., Fink, A. A., \& Boudreau, J. W. Investing in people: Financial impact of human resource initiatives. Alexandria: Society for Human Resource Management, 2019. $428 \mathrm{p}$.

15. Kazmi, S., Hasnu, S., Jamil, R. Creating a Link between HR Departmentand Budgeting: What Do HR Managers Think? American Journal of Economics and Business Administration. 7(1). URL: https://ssrn.com/abstract=2616387

16. SHRM. What is involved in developing an HR budget? 2019. URL: https://www.shrm.org/resourcesandtools/ tools-and-samples/hr-qa/pages/whatneedstobeincludedinanhrbudget.aspx

\section{REFERENCES:}

1. Bersuts'ka S.Ya. \& Zhukov S.A. (2017) Sotsial'na rol' systemy byudzhetuvannya na promyslovykh pidpryyemstvakh Ukrayiny. Nauchnyy vestnyk Donbasskoy hosudarstvennoy mashynostroytel'noy akademyy, 1, 112-119. (in Ukrainian)

2. Havkalova N.L. \& Kryvoruchko A.S. (2011). Protsedura optymizatsiyi vytrat na personal. Teoriya ta praktyka derzhavnoho upravlinnya, 4, 156-161. (in Ukrainian)

3. Hutsal O.P. (2014) Byudzhet vytrat na personal u systemi byudzhetiv pidpryyemstva. Sotsial'no-trudovi vidnosyny: teoriya ta praktyka, 1, 402-407. (in Ukrainian)

4. Dykan' V.L. \& Zayets' H.P. (2018) Zabezpechennya efektyvnosti menedzhmentu promyslovykh pidpryyemstv na zasadakh upravlinnya vytratamy na personal. Visnyk ekonomiky transportu i promyslovosti, 62, 297-305. (in Ukrainian)

5. Dyachkov D.V., Buryy Ye.I., \& Vovkovins'kyy Yu.V. (2018) Optymizatsiyne upravlinnya vytratamy na personal $\checkmark$ umovakh ekonomichnoyi nestabil'nosti. Ekonomichnyy forum, 1, 165-171. (in Ukrainian)

6. Zhukov S.A. (2017) Rol' byudzhetuvannya v systemi stratehichnoho upravlinnya lyuds'kym kapitalom promyslovoho pidpryyemstva. Ekonomichnyy visnyk Donbasu, 2(48), 214-219. (in Ukrainian)

7. Zbryts'ka T.P. \& Salo Ya.V. (2019) Audyt personalu: navchal'nyy posibnyk. Odesa: ONEU, 381 p. (in Ukrainian)

8. Serdyuk Ya.V. (2016) Byudzhetuvannya yak skladova finansovoho planuvannya na pidpryyemstvi. Mizhnarodnyy naukovyy zhurnal «Internauka», 12(22), 141-145. (in Ukrainian)

9. Synytsina Yu.P., Dunaychuk S.M. \& Alyekseenko A.I. (2017) Upravlinnya vytratamy na personal na osnovi systemnoho pidkhodu. Ekonomika i suspil'stvo, 9, 636-641. (in Ukrainian)

10. Synyayeva L.V. (2017) Vzayemozv'yazok planuvannya vytrat na personal z kryteriyamy efektyvnosti. Biznes-inkubator. Retrieved from: http://elar.tsatu.edu.ua/bitstream/123456789/4694/1/5-1-74-77.pdf (in Ukrainian)

11.Danyuk V.M. (2013) Upravlinnya personalom. Kyyiv: KNEU; Kramators'k: NKMZ, 666 p. (in Ukrainian)

12. Feshchenko L.V. (2011) Vdoskonalennya byudzhetnoho planuvannya i prohnozuvannya. Visnyk ekonomiky transportu i promyslovosti, 34, 154-157. (in Ukrainian)

13. Yuvzhenko N.M. (2018) Tradytsiyni ta suchasni metody byudzhetuvannya: perevahy i nedoliky. Biznes Inform, 7, 239-245. (in Ukrainian)

14. Cascio W.F. Fink A.A. \& Boudreau J.W. (2019) Investing in people: Financial impact of human resource initiatives. Alexandria: Society for Human Resource Management.

15. Kazmi S., Hasnu S., Jamil R. (2015) Creating a Link between HR Departmentand Budgeting: What Do HR Managers Think? American Journal of Economics and Business Administration, 7(1). Retrieved from: https://ssrn.com/abstract=2616387

16. SHRM (2019) What is involved in developing an HR budget? Retrieved from: https://www.shrm.org/resourcesandtools/tools-and-samples/hr-qa/pages/whatneedstobeincludedinanhrbudget.aspx 